NBER WORKING PAPER SERIES

\title{
ECONOMIC INSIGHTS FROM INTERNET AUCTIONS: A SURVEY
}

\author{
Patrick Bajari \\ Ali Hortacsu \\ Working Paper 10076 \\ http://www.nber.org/papers/w10076 \\ NATIONAL BUREAU OF ECONOMIC RESEARCH \\ 1050 Massachusetts Avenue \\ Cambridge, MA 02138 \\ November 2003
}

The views expressed herein are those of the authors and not necessarily those of the National Bureau of Economic Research.

C2003 by Patrick Bajari and Ali Hortacsu. All rights reserved. Short sections of text, not to exceed two paragraphs, may be quoted without explicit permission provided that full credit, including (C) notice, is given to the source. 
Economic Insights from Internet Auctions: A Survey

Patrick Bajari and Ali Hortacsu

NBER Working Paper No. 10076

November 2003

JEL No. L1, D8

\section{ABSTRACT}

This paper surveys recent studies of Internet auctions. Four main areas of research are summarized.

First, economists have documented strategic bidding in these markets and attempted to understand why sniping, or bidding at the last second, occurs. Second, some researchers have measured distortions from asymmetric information due, for instance, to the winner's curse. Third, we explore research about the role of reputation in online auctions. Finally, we discuss what Internet auctions have to teach us about auction design.

Patrick Bajari

Department of Economics

Duke University

219B Social Science Building

Durham, NC 27708-0097

and NBER

bajari@econ.duke.edu

Ali Hortacsu

Department of Economics

University of Chicago

1126 East 59th Street

Chicago, IL 60637

and NBER

hortacsu@uchicago.edu 


\title{
Economic Insights from Internet Auctions: A Survey.
}

\author{
Patrick Bajari and Ali Hortacsu ${ }^{1}$ \\ October 18, 2003
}

\subsection{Introduction.}

Electronic commerce continues to grow at an impressive pace despite a number of widely publicized failures by prominent online retailers. According to the Department of Commerce, total retail e-commerce in the United States in 2002 exceeded \$45 billion, a 27 percent increase over the previous year. Online auctions are one of the most successful forms of electronic commerce. In 2002, more than 632 million items were listed for sale on the web behemoth eBay alone, a 51 percent increase over the previous year. This generated gross merchandise sales of more than $\$ 15$ billion.

The rapid development of these markets is usually attributed to three factors. ${ }^{2}$ The first is that online auctions provide a less costly way for buyers and sellers on locally "thin" markets such as specialized collectibles to meet and conduct transactions. Cohen (2002, p. 45) states, "It would be an exaggeration to say that eBay was built on Beanie Babies, but not by much". 3 In May 1997, nearly \$500,000 worth of Beanie Babies was sold on eBay. This was 6.6 percent of overall sales. While it may be difficult to find a particular Beanie Baby locally, such as Splash the Whale or Chocolate the Moose, you have a good chance of finding it online. Collectibles such as Beanie Babies, first edition books, Golden Age comics, and Elvis paraphernalia are among the thousands of categories actively traded in online auctions.

A second factor is that online auction sites substituted for more traditional market intermediaries such as specialty dealers in antiques, sports cards, and other collectibles.

\footnotetext{
${ }^{1}$ Affiliations: Duke University and NBER, and University of Chicago and NBER, respectively. We thank the editor, two anonymous referees, Ginger Jin, Axel Ockenfels, David Reiley, Paul Resnick and Alvin Roth for their very detailed and insightful comments on various drafts of this document.

${ }^{2}$ There are several interesting accounts of the early development of Internet auctions. Cohen (2002) chronicles the development of eBay through in depth interviews of eBay founders, executives and users. Lucking-Reiley (2000) provides an insightful description of Internet auction sites and auction mechanisms across different market segments.

${ }^{3}$ Beanie Babies are stuffed dolls that are popular among collectors.
} 
For instance, an antique dealer from Seattle explained why he closed his store on an eBay message board:

A couple of years or so ago my best buyers started spending their money at eBay. Then my pickers started selling on eBay instead of selling to me. Then when I went to the flea market and asked how much an item was, I got quoted what one sold for on eBay not what the seller wanted for the item. I have a toy show that sold out for years, but nowadays all my vendors sell on eBay, and all the buyers are spending their money on eBay. I used to buy and sell a lot in the toy magazine before they got reduced to mere pamphletsized rags... Get my drift? (Cohen, p.110)

Online auctions have extensive listings and powerful search technologies that create liquid markets for specialized product categories. Due to the resulting reduction in transaction costs, some intermediaries like the antique dealer above have been forced to exit the market.

Finally, online auctions can be fun! Many users of online auctions clearly enjoy contemplating the subtleties of strategic bidding, and sharing their insights with others. Most online auction sites have active message boards that provide collectors with a sense of community and where one can learn the fine points of collecting.

In this paper, we shall survey recent research concerning online auctions. First, we describe the mechanics of the auction rules used on the most popular sites and some empirical regularities about bidding. An especially interesting empirical regularity is that bidders frequently snipe, that is, they strategically submit their bids at the last seconds of an auction that lasts several days. Several authors have empirically examined sniping and proposed explanations. Examples include Ku, Malhotra, and Murnighan (2003), Wilcox (2000), Ockenfels and Roth (2002), Hasker, Gonzales and Sickles (2002) and Bajari and Hortacsu (2003). 
We then survey a growing literature in which researchers have attempted to document and quantify distortions from asymmetric information on online auction markets. As pointed out by Kazumori and McMillan (2003), the "information asymmetry" problem constitutes perhaps the biggest limitation posed to the impressive growth of online auctions. In online auctions transactions take place between complete strangers who may not live in the same state or the same country, making it very difficult for buyers to directly inspect the goods, or to make sure that the good will be delivered at all. This creates opportunities for misrepresentation of objects and fraudulent behavior by sellers, which may limit trade in these markets. ${ }^{4}$

The informational asymmetry may manifest itself as a severe "winner's curse" problem, in which bidders recognize that winning an auction is conditional on them being the most optimistic among their competitors regarding the honesty of the seller. Auction theory then predicts that bidders will respond strategically to the "winner's curse" by lowering their bids, thus leading to lower prices and volumes in these markets. In section 4, we will survey empirical work by Jin and Kato (2002), Bajari and Hortacsu (2003), and Yin (2003) that use detailed data from online auction sites to test whether bidders indeed act strategically in the face of a possible "winner's curse," and whether this strategic response is large enough to prevent fraudulent sellers from extracting (shortterm) rents.

Given the above discussion, a very important component of the online auction business is to decrease the informational asymmetries between market participants. A particular popular method, pioneered by eBay, is the use of feedback mechanisms that allow buyer and sellers to leave publicly available comments about each other. We will survey a rapidly growing empirical literature that utilizes data from the feedback mechanisms of online auction sites to quantify the market value of "online reputations," as defined by various summary statistics of user feedback. ${ }^{5}$

\footnotetext{
${ }^{4}$ A number of high profile incidents of fraud have occurred on online auctions. For instance, the FBI launched an investigation called "Operation Bullpen" that led to an indictment of 25 persons for selling tens of millions of dollars of forged collectibles such as forged signatures from Babe Ruth and Lou Gehrig (Cohen, p. 308).

5 Another survey article that provides a more in-depth survey of theoretical models of reputation is Dellarocas (2002).
} 
The study of Internet auction sites, with the wide variety of auction formats and rules they offer, can also give us some valuable insights regarding auction design. On many Internet auction sites, sellers are allowed to fine tune their auctions by experimenting with minimum bids or secret reserve prices. Several sites also allow the sellers to make choices regarding which auction format to use. Auction theory often has specific predictions about which auction format to use, or what the optimal minimum bid or secret reserve price should be, depending on whether the seller's objective is to maximize revenues or efficiency.

In section 6, we discuss the question of the choice of auction format. We first survey empirical tests of the celebrated Revenue Equivalence Theorem of Vickrey (1961), Myerson (1981), and Riley and Samuelson (1981) using field experiments conducted on the Internet, focusing on the work of Lucking-Reiley (1999). Although the Revenue Equivalence Theorem presents a theoretical benchmark that suggests the choice of auction format is irrelevant. The widespread use of ascending auction formats on Internet auction sites suggests revenue equivalence may not hold in these markets. We survey empirical research by Ivanova-Stenzel and Salmon (2003) that investigates whether bidders prefer some auction formats over others, and what explains these preferences.

In section 6, we also discuss the use of minimum bids and secret reserve prices. Empirical work by Lucking-Reiley (1999), Bajari and Hortacsu (2003) and Morgan and Hossain (2003) describe how sellers set these bids and empirically study optimal reserve price policies. We discuss these findings papers in the context of a large theoretical literature on optimal auction design, including Myerson (1981), Bulow and Roberts (1989), Levin and Smith (1994), McAfee, Vincent and Quan (1994), Milgrom and Weber (1982), McAfee, Vincent and Quan (1994) and Vincent (1992), McAfee-McMillan (1992).

\subsection{Buying and Selling in Online Auctions.}

On any given day, sellers list millions of items on online auctions. On the largest sites, such as eBay, Amazon or Yahoo, buyers need to locate their desired product from a pool with a mind boggling array of listings. These sites facilitate search in two ways. First, the sites have a carefully designed set of categories and subcategories to organize the listings. For instance, eBay's main page lists general categories such as antiques, art, 
clothing, coins and stamps. If you click on the category art, you will be led to subcategories, such as drawings, paintings and prints. Within a subcategory, there may be multiple layers of additional categories. For instance, the subcategory of paintings includes Antique American and Modern European. These categories are carefully designed by the auction site to facilitate buyers' search. Within a given category, the listings are described with a short heading. Buyers can sort the listings by closing time, new listings or the current high bid. Secondly, users can search the millions of listings by keywords, category, price range and completed items. This allows users to gather considerable information about similar products which is of course useful for forming a bid.

In figure 1, we display a listing from eBay. The web page describes the item for sale, which in this case is a collection of signatures from 14 Nobel laureates in economics. The user can see the current high bid, the time left in the auction, the identity of the seller and the high bidder, and sometimes a seller supplied picture of the item for sale. The web page describes the item for and sometimes displays a seller supplied picture. The listing also displays the seller's feedback to the right of the seller's identity. Users on eBay can leave each other feedback in the form of positive, neutral and negative comments. The total feedback is the sum of positive comments minus the number of negative comments. eBay also computes the fraction of positive feedback received by the seller.

The listing displays the minimum bid and whether the seller is using a secret reserve. The minimum bid is analogous to a reserve price in auction theory. That is, the seller will not release the item for less than the minimum bid. A secret reserve price functions similarly except that it is not publicly displayed to the bidders. Bidders can only see whether or not the secret reserve is met. Sellers on eBay pay an insertion fee and a final value fee. The insertion fee is based on the minimum bid set by the seller. For instance, if the minimum bid is between $\$ 25$ and $\$ 50$, the insertion fee is currently $\$ 1.10$. The final sale fee is a non-linear function of the final sale price. For items with a final sale price of less than $\$ 25$, the fee is 5.25 percent of the final sales price. Higher sales prices 
are discounted at the margin. In addition, eBay has additional fees for instance if a secret reserve is used or if more than one picture is used. ${ }^{6}$

At the bottom of the listing, buyers can submit their bid. Most online auctions use some variant of proxy bidding. Here's how it works. Suppose that a seller lists an Indian head penny for sale with a minimum bid of $\$ 15.00$. At this price-level, eBay requires a bid increment of $\$ .50$ to outbid a competitor. ${ }^{7}$ If bidder A places a proxy bid of $\$ 20$, the eBay computer will submit a bid of $\$ 15.00$, just enough to make bidder A the high bidder. Suppose that bidder B comes along and submits a bid of $\$ 18.00$. Then the eBay computer will update A's bid to $\$ 18.50$ (the second highest bid plus one bid increment). The proxy bidding system updates A's bid automatically, until A is outbid by another bidder. If this occurs, the bidder will be notified by email and given a chance to update her bid. This process continues until time in the auction runs out.

\subsection{Last Minute Bidding.}

Bids commonly arrive during the last seconds of an Internet auction that lasts as long as several days. For instance, Roth and Ockenfels (2002a) find in sample of 240 antique auctions on eBay, 89 had bids in the last minute and 29 in the last 10 seconds. Other researchers, including Wilcox (2000), Bajari and Hortacsu (2003), Haskins (2003) and Schindler (2003) have documented similar patterns. In this section, we summarize some of the proposed explanations for last minute bidding and the related empirical work.

Last minute bidding is difficult to explain using standard auction theory. Proxy bidding bears a strong similarity to the second-price sealed-bid auctions since, in both cases, the payment by the winning bidder is equal to the second highest bid. Vickrey (1961) observed that in a second-price sealed-bid auction with private values, it is a weakly dominant strategy for a bidder to bid her reservation value. The intuition is simple. If the bid is less than her private value, there is a probability that she will lose the auction. However, the payment the winning bidder makes only depends on the second highest bid. As a result, bidding one's valuation weakly increases ones payoff. Thus at

\footnotetext{
${ }^{6}$ The fees that eBay charges have been updated several times, with vocal dissent from eBay sellers in certain instances, such as when eBay decided to charge a $\$ 1$ fee to use the secret reserve option (Wolverton (1999)). Also, see Park (2002) for some evidence on the impact of network effects on the competition (in listing-fees) between eBay and Yahoo!

${ }^{7}$ eBay has a sliding scale of bid increments, based on the current price level in an auction.
} 
first glance, it appears that bidders can leave their proxy agents do their bidding, and not need to wait until the last seconds of the auction.

However, this is clearly not what happens in practice and therefore several explanations for late bidding have been proposed in the literature. A first explanation, which departs only slightly from the independent private values environment, is proposed by Ockenfels and Roth (2002b) to argue that late bidding maybe a form of "tacit collusion" by the bidders against the seller. In their model, bidders can choose to bid early or late. However, a late bid might not be successfully transmitted due to network traffic. There are (at least) two possible equilibrium in their model. In the first, agents bid early in the auction and in the second agents only bid at the last second. Bidding late is a risk because the bids may not be successfully transmitted. On the other hand, late bidding softens competition compared to the first equilibrium.

Ockenfels and Roth (2002b) demonstrate that this "tacit collusion" explanation of last minute bidding equilibrium hinges on the assumption that there is a hard deadline for submitting bids. While eBay auctions have a hard deadline, Amazon auctions are automatically extended if a late bid arrives. Ockenfels and Roth demonstrate that late bidding is no longer an equilibrium in Amazon style auctions. They conclude that there are more powerful incentives for late bidding in eBay auctions than in Amazon auctions.

As a test of this theory, Ockenfels and Roth (2002a) compare the timing of bids for computers and antiques on Amazon and eBay. They find that late bidding appears to be more prevalent on the eBay auctions. On eBay, bids are submitted within the last five minutes in 9 percent of the computer auctions and 16 percent of the antique auctions. On Amazon, about 1 percent of the auctions in these categories receive bids in the last five minutes. Bidder surveys reveal late bidding on eBay is a deliberate strategy meant to avoid a "bidding war". Confirming evidence comes from Schindler (2003), who studies bidding in Yahoo auctions for computer, art and cars. In these auctions, the sellers can choose to have a hard close or an automatic extension, similar to Amazon auctions, if late bids arrive. She finds that, consistent with the Roth and Ockenfels model, the winning bidder tends to arrive later in the auctions with a hard ending for all three product categories. 
Roth and Ockenfels and Schindler's empirical finding that there is less sniping in flexible ending rule auctions is not universally confirmed, however. Ku, Malhotra, and Murnighan (2003) study bidding in online auctions in several U.S. cities for art that has been publicly displayed. The proceeds of the auctions were donated in part to charitable causes. The authors observe online auctions with both hard endings and flexible endings. They observe substantially less late bidding than the previously mentioned studies. For instance, they find that only 1.6 percent of the bids arrive in the last 5 minutes of the auctions with hard deadlines while only .5 percent in the auctions with flexible endings. Also, $\mathrm{Ku}$, Malhotra, and Murnighan (2003) find that for auctions with flexible endings, a greater percentage of the bids arrive in the last hour and the last day than for auctions with hard endings. This is not qualitatively consistent with the Roth and Ockenfels (2002) prediction. However, it is important to note that because of the nature of their data, the authors have limited controls for heterogeneity across auctions that are held in different cities.

Notwithstanding Ku, Malhotra and Murnighan's finding, several other empirical researchers have examined the "tacit collusion" hypothesis of Ockenfels and Roth (2002) further. Hasker (2003) tests the Ockenfels and Roth theory by examining bids for computer monitors on eBay. If late bids soften competition and lower the probability of price wars, then the distribution of the winning bids conditional upon a snipe should not be equal the distribution of the winning bids if no snipe occurs. Hasker finds that, in most of the specifications he examines, he is unable to reject the equality of these two distributions. He argues that this is inconsistent with the "tacit collusion" theory. Similarly, in a data set of bidding for eBay coin auction, Bajari and Hortacsu (2003) find that reduced form regressions suggest that early bidding activity is not correlated with increased final sales prices. Schindler's (2003) study also casts some doubt on the "tacit collusion" on the revenue front. Under private values, the Ockenfels and Roth (2002) model predicts that a hard close will decrease revenues for the seller. ${ }^{8}$ Schindler finds that sellers more frequently use auctions with automatic extensions for art ( $82 \% \mathrm{v} .18 \&)$, cars $(73 \%$ v. $27 \%)$ but not for computers (91\% v. 9\%). Therefore, under the Roth and

\footnotetext{
${ }^{8}$ However, this revenue ranking maybe reversed in an affiliated interdependent values environment.
} 
Ockenfels (2002b) theory, the first two categories are consistent with seller revenue maximization while the last category is not.

A second explanation, also offered by Roth and Ockenfels' (2002), is the presence of naïve bidders on eBay who do not understand the proxy-bidding mechanism, and hence bid incrementally in response to competitors' bids. ${ }^{9}$ Ockenfels and Roth (2002) demonstrate that last-minute bidding is a best-response by rational bidders against such naïve bidders. Roth and Ockenfels (2002) present some survey evidence to support this hypothesis. More tellingly, Ariely, Ockenfels and Roth (2003) conduct a controlled laboratory experiment in which one of the experimental treatments is an eBay-type fixeddeadline auction, where the probability of "losing" a bid due to transmission error is zero. Notice that this feature rules out the "tacit collusion" explanation; however, it is still a best-response against naïve incremental bidders to bid at the last second. Accordingly, Ariely, Ockenfels and Roth (2003) find a significant amount of late-bidding activity in this experimental treatment.

A third explanation is based on a common value. In a common value auction, such as Wilson's (1977) mineral rights model, the item up for sale has a true value $V$ that is not directly observed by the bidders. For example, the common value $V$ could be the resale value of a collectible. Each bidder receives an imperfect signal $x$ of $V$ which is private information. By bidding early, a bidder may signal information about $x$ to other bidders and cause them to update their beliefs about $V$. Conditional on winning, this may increase the price that a bidder has to pay for the item. Bajari and Hortacsu (2003) formalize this intuitionand demonstrate that last minute bidding occurs in models of online auctions with a common value - in fact they show that in a symmetric common value environment, the eBay auction can be modeled as a sealed-bid second price auction. A similar result is also provided in Ockenfels and Roth (2002b) in a simpler setting. This explanation also finds some support in the data. Roth and Ockenfels (2002a) report that there is more last-minute bidding on eBay antiques auctions than in eBay computer auctions. They argue that antiques auctions are more likely to possess a

\footnotetext{
${ }^{9}$ Based on survey data, Ku, Malhotra, and Murnighan (2003) also find that some bidders maybe driven by emotional factors, which they label as "competitive arousal." For instance, one survey respondent from Cincinnati who purchased a ceramic pig explained her actions as follows: "[I] really wanted the pig, and probably also got caught up in the competitive nature of the auction." Another respondent explained her behavior by stating, "Auction fever took over."
} 
common value element than computer auctions, and hence that the observed pattern is consistent with the theoretical prediction.

A fourth explanation for late bidding is proposed by Wang (2003), who studies a model in which identical items are simultaneously listed, as opposed to the usual assumption that only a single unit of the item is up for sale. Last minute bidding is part of the unique equilibrium to his model. Peters and Severinov (2003) argue that their model of bidding for simultaneous listings of identical objects is also qualitatively consistent with late bidding. Taken together, these two papers suggest that the multiplicity of listings is another explanation for late bidding. However, it is not clear whether the Wang (2003) and Peters and Severinov (2003) models predict that last minute should be less prevalent on Amazon as opposed to eBay.

A fifth explanation is given by Rasmusen (2001), who considers a model in which bidders have uncertainty about their private valuation for an item. As in the model of Levin and Smith (1994), he assumes that some bidders must pay a fixed fee to learn their private information. This is not an unreasonable assumption in online auctions. In order to learn their private valuations, bidders will inspect the item and may search for sales prices of previously listed items. The fixed fee can be thought of as the opportunity cost of time required to do this research. Rasmusen demonstrates that late bidding can occur because bidders wish to economize on the costs of acquiring information.

The multiplicity of explanations provided in the literature regarding the causes of a seemingly innocuous phenomenon like last-minute bidding is a great example of how the analysis of online auctions enables us to appreciate the richness and complexity of strategic interaction in markets. The preceding discussion also illustrates how a seemingly simple empirical regularity can have multiple explanations, and that it is not easy to tell between these explanations without creative exploitation of sources of variation in the data. In this regard, the experimental study of Ariely, Ockenfels and Roth (2003) is a good demonstration of laboratory experiments can complement data obtained from real markets to help explain complex strategic interactions.

\subsection{The Winner's Curse.}

In online markets, buyers are not able to perfectly observe the characteristics of the goods for sale. In the market for collectibles and other used goods, buyers value objects 
that appear new. Scratches, blemishes or other damage will lower collectors' valuations. Since a buyer cannot directly touch and see the object over the Internet, it may be hard to assess its condition. This introduces a common value component into the auction and therefore bidders should account for the winner's curse.

The winner's curse can be illustrated by the following experiment (Business Week, March 20, 2002 “Online Auctions: Going, Going, Gone Sucker”):

Paul Klemperer ... illustrates the winner's curse to his students by auctioning off a jar with an undisclosed number of pennies. The students bid a little below their estimate of the jar's contents to leave a profit. Every time, though, the hapless winner of the jar is the student who overestimates the number of pennies by the greatest amount, and therefore overpays by the most.

The winner's curse occurs when bidders do not condition on the fact that they will only win the auction when they have the highest estimate. If there are a large number of bidders, the highest estimate may be much larger than the average estimate. Therefore if the winner bids naively, he will overpay for the item. In addition to the classroom experiment above, a number of experimental studies find that inexperienced bidders frequently are subject to the winner's curse (see Kagel and Roth (1995) for a survey of the experimental literature).

Several authors empirically examine whether bidders are subject to the winner's curse and, more generally, measure distortions from asymmetric information in online markets. Two main methodologies have been utilized to answer this question so far. The first method, utilized by Jin and Kato (2002), is to sample goods in an actual market, and determine whether the "market price" reflects the ex-post quality of the goods they buy. Online auctions present perhaps a unique opportunity in the utilization of this methodology, since items sold in these markets are inexpensive enough to allow researchers to "shop" out of their own pockets or research grants.

In particular, Jin and Kato (2003) study fraudulent seller behavior in the market for Internet baseball cards. Fraud on Internet auctions is a problem, for instance, the Internet 
Fraud Center states that 48 percent of the 16,775 complaints lodged in 2001 were from online auctions. In this market, Jin and Kato find that sellers frequently misrepresent how baseball cards will be graded.

Professional grading services are commonly used for baseball cards. Grading services produce a ranking from 1 to 10 based on the condition of the card. Cards that are scratched or have bent corners are assigned lower grades than cards that are in mint condition. Jin and Kato bid in eBay auctions for ungraded cards and then submitted the cards to a professional graded service. ${ }^{10}$ Their sample contained 100 ungraded baseball cards. Of these, 19 claimed that they had a ranking of 10 (gem mint), 47 claimed mint (9 or 9.5), 16 nearmint-mint ( 8 or 8.5$), 7$ near mint ( 7 or 7,5). 11 cards had no claim.

Many sellers of ungraded cards misrepresented the card quality. Among sellers who claimed that their cards were grade 9 to 10, the average grade was 6.34. In comparison, the average grade of cards claiming 8.5 or below was 6.87 . The price difference between a grade 10 and a grade 6.5 for some cards could be hundreds or thousands of dollars. Jin and Kato find evidence that some buyers were misled by these claims. Buyers were willing to pay $27 \%$ more for cards that were self reported as 9 to 9.5 and $47 \%$ for cards that were reported as 10 . They conclude that some buyers have underestimated the probability of fraud and therefore have fallen prey to the "winner's curse."

To establish whether the "winner's curse" problem is more of an issue on online as opposed to offline markets, the authors employed male agents between 25-35 years of age to purchase the same types of cards from retail collectibles stores in 11 metropolitan districts, and found that the fraud rate there (3.2\%) was much lower than online $(11 \%)$. Moreover, in their retail purchases, the authors found that retail sellers were more reluctant to quote the likely grade of the cards when one was not available.

One caveat with this study is that the winner's curse problem that the authors allege apply to items that are mundanely priced (between $\$ 60$ and \$150). For instance, Jin and Kato report that the average eBay price for a graded 10 Ken Griffey Jr.'s 1989 Upper Deck Card (the most actively traded card on eBay) is $\$ 1,450$. An ungraded Griffey with a self claim of 10 only sold for an average of $\$ 94.26$. Jin and Kato's estimates imply that

\footnotetext{
${ }^{10}$ They attempted to bid just enough to win the auction and to have a minimal effect on the actions of other players.
} 
this self claim generated an extra $\$ 30$ in revenue. If bidders naively took the claims at face value, this would have generated a mistake of over $\$ 1,300$ - hence the Ken Griffey example shows that bidders by and large do correct for the "winner's curse." The contention is whether the bidders correct for this enough. Also, the authors did manage to purchase a card of mint 9 from their ungraded group. Apparently, taking a chance with ungraded cards sometimes does in fact pay off.

Although Jin and Kato's (2002) method to assess the prevalence of fraud and the magnitude of the corresponding "winner's curse" response by buyers provides for precise measurements, it would be difficult, if only due to budget constraints, to replicate this methodology to examine markets for more expensive items like computers or automobiles (which are actively traded on eBay). Hence, the second set of papers we will survey utilize more "indirect" methods that rely on testing the implications of strategic bidding in common value auction models (in which bidders account for the presence of a “winner's curse.”)

The first study we will summarize in this regard is Bajari and Hortacsu (2003), who examine the effect of a common value on bidding for collectible coins in eBay auctions. The authors first argue that bidding in an eBay auction in the presence of a common value element can be modeled as bidding in a second-price sealed-bid auction with common values (and uncertain number of opponents). The reasoning is based on the observation of "sniping" in these auctions: the presence of a common value element in an eBay auction suggests that bidders should wait until the last minute in order to avoid revealing their private information. If all bids arrive at the last minute, a bidder will not be able to update his beliefs about the common value $V$ using the bids of others - hence his bidding decision will be equivalent to that of a bidder in a sealed-bid second-price auction.

Given this argument, the authors then test for the presence of a common value element using an idea first proposed by Paarsch (1992) ${ }^{11}$. If the auction environment is one with purely private values, it is a dominant strategy for bidders to bid their private

\footnotetext{
${ }^{11}$ We should note, however, that Paarsch (1992) implemented his idea in the context of first-price auction, where the comparative static with respect to the number of bidders in the auction is ambiguous. See Athey and Haile (2002) and Haile, Hong and Shum (2003) for more rigorous derivations of this comparative static result in the context of second-price and ascending (button) auctions.
} 
values, independent of the number of competitors that they face. If there is a common value element, however, the bids will depend on the number of bidders present. This is because when there are more bidders, the possibility of suffering a "winner's curse" conditional on winning the auction is greater, further cautioning the bidders to temper their bids to avoid the curse.

Bajari and Hortacsu (2003) implement this using cross-sectional regressions of bids on the number of bidders, using various instruments to account for the endogeneity of the number of bidders in the auction. Consistent with the presence of a common value element, they find that bids are declining with the number of competing bidders. They test whether bidders with little eBay experience tend to bid systematically higher, by regressing individual bids on total eBay feedback. While they find a statistically significant effect on bids, it is very small in magnitude. This is not consistent with experimental evidence that suggests inexperienced participants overbid, and hence are more likely to suffer from a "winner's curse."

Next, the authors attempt to directly measure the distortions from asymmetric information by estimating a structural model. In their structural model, the data generating process is a Bayes-Nash equilibrium where: 1) there is a common value, 2) bidders have to pay a fixed cost to learn their signal $x$, and 3 ) entry is endogenously determined by a zero profit condition. Given this structural model, they estimate the parameters for the distribution of the common value $V$, the distribution of bidder's private information $x$ and the parameters that govern entry decisions.

The authors find that bidder's prior information about $V$ is quite diffuse. In their model, ex ante beliefs about $V$ are normally distributed. The standard deviation is 0.56 times the book value of the coin if there is no blemish and 0.59 time the book value if there is a blemish. For instance, the distribution of the common value for a coin with a book value of $\$ 100$ with no blemish is $\$ 56$. However, the distribution of $x$ has much lower variance than $V$. For instance, the distribution for $x$ for the coin described above would be normally distributed with a mean equal to $V$ and standard deviation $\$ 28$. After a buyer has spent the time and effort to research a coin, his estimate $x$ is considerably more precise than his prior information about $V$. 
Given their parameter estimates, the authors simulate their structural model to quantify the distortions from asymmetric information. First, the compute the equilibrium bidding strategies for an auction where all of the covariates are set equal to their sample averages (most importantly, the book value is equal to $\$ 47$ ). The bid functions are roughly linear. In this auction, bidders shade their bids to be $\$ 5.50$ less than their signals $x$. Given their uncertainty about $V$, the buyers bid 10 percent less than their signals to compensate for the winner's curse. Second, they simulate the impact of adding an extra bidder on expectation (since bidders arrive at random). When the expected number of bidders increase, the winner's curse is more severe. Bajari and Hortacsu find that for an auction with all characteristics set equal to their sample averages, adding an additional bidder reduces equilibrium bids by 3.2 percent as a function of the bidder's signal $x$. Finally, they study the effect of lowering the variance of $V$ from 0.52 times the book value to 0.1 . They find that the bid function shifts upwards by $\$ 2.50$.

There are two main limitations to their analysis. First, the results depend on correctly specifying both the game and the parametric assumptions used in the structural model. The common value model that they use is fairly strict. All players are perfectly rational, symmetric, and have normally distributed private information. However, they note that it is not computationally tractable, with current methods, to generalize the model since computing the equilibrium involves high dimensional numerical integration. Second, unlike Yin (2003) or Jin and Kato (2002), the authors do not have rich ex post information about the realization of the common value or for bidder uncertainty.

In a related study, Yin (2003) utilizes comparative static predictions of the common value second-price auction model to test for the presence of common values in eBay auctions for used computers. Based on numerical simulations, Yin establishes that bidding strategies in the common value second price auction model respond strongly to changes in the variance of $x$, a bidder's private signal about $V$. Holding $V$ fixed, if the variance of $x$ increases, the bidder is more likely to be subject to the winner's curse. Conditional on winning, the value of $x$ should be larger holding $V$ fixed. Therefore, bidders should behave more conservatively.

Yin supplements her data set with survey information in order to understand how changing the variance of the signal $x$ influenced bidding. To do this, she downloaded the 
web pages for 223 completed auctions and asked survey respondents from the Internet to reveal their estimates, $x$, purging information about the bids and the reputation of the seller from the web page so that the survey responses would primarily reflect bidders' ex ante beliefs about the item for sale and not the seller characteristics. By computing the variance of an average 46 such responses per auction, she constructed a proxy for the variance of $x$. The highest variance occurred in the auctions where the seller poorly designed the web page or where the object for sale had inherently ambiguous characteristics.

Yin finds that the winning bid is negatively correlated with the normalized variance of the survey responses. This is illustrated in figure 2. The vertical axis is the winning bid divided by the average survey response. The horizontal axis is the variance of the responses, divided by the average response. For an auction where the normalized variance was 0.4 , the expected value of the normalized winning bid was 0.7 . As the variance increased to 1.3 , the expected value of the normalized winning bid was less than 0.2. Given that the auctions were for computers worth hundreds of dollars, these are fairly large magnitudes.

One interpretation of these results is that bidders act as if they understand the winner's curse. The bidders are reluctant to submit high bids when they are uncertain about the condition of the used computer, as reflected by a high variance in $x$. On the other hand, if they are more certain about what they are purchasing, they will bid with more confidence. These findings suggest that asymmetric information can generate significant distortions and therefore sellers have a strong incentive to communicate what they are selling by designing a clear web page to reduce bidder uncertainty.

A potential limitation to Yin's analysis is that the variance of $x$ for survey respondents may be an imperfect measure of the variance of $x$ for the real bidders. The survey respondents' reservation values are roughly twice the final sales price on average. Perhaps they are not well informed about used computer prices. On the other hand, if the winner's curse is a strong possibility, it may be an equilibrium for a bidder to shade his bid to be one half of his estimate $x$.

Conditional on their caveats, all three papers surveyed in this section suggest that the "winner's curse" is an important concern in the eBay markets analyzed (baseball cards, 
collectible coins, used computers). Two of the three papers, Bajari and Hortacsu (2003) and Yin (2003), find evidence that bidders strategically respond to the presence of of a winner's curse. Jin and Kato (2002) also present similar evidence of strategic "bidshading," but, through their ex-post appraisal of cards sold on eBay, they argue that the amount of bid-shading by bidders in the baseball cards market is not large enough.

As pointed out in the introduction, an important implication of these results, noted by Kazumori and McMillan (2003), is that depressed prices due to "winner's curse" may limit the use of online auctions by sellers to items for which informational asymmetries do not play a very large role. Kazumori and McMillan (2003) report that after several years of experimentation with running art auctions on the Internet in partnership with eBay, Sotheby's decided to discontinue selling art on the Internet as of May 2003. As the authors note, there may have been several confounding factors that led to the failure of Sothebys.com. Fortunately, this still leaves the investigation of the question "which goods can be sold using online auctions" open for further empirical and theoretical analysis.

\subsection{Reputation Mechanisms.}

Perhaps the most important source of information asymmetry on online auctions, aside from the inability to physically inspect goods, is the anonymity of the sellers. For instance, eBay does not require its users to divulge their actual names or addresses; all that is revealed is an eBay ID ${ }^{12}$. There are also very few repeat transactions between buyers and sellers. For instance, Resnick and Zeckhauser (2001), using a large data set from eBay, report that fewer than $20 \%$ of transactions are between repeated buyer-seller pairs within a five-month period. ${ }^{13}$ This obviously limits a buyer's information about the seller's reliability and honesty.

To ensure honest behavior, online auction sites rely on voluntary feedback mechanisms, in which buyers and sellers alike can post reviews of each others' performance. On eBay, a buyer can rate a seller (and vise versa) by giving her a positive

\footnotetext{
${ }^{12}$ Sellers are also required to list a valid credit card number.

${ }^{13}$ Resnick and Zeckhauser (2001) had data on transactions conducted on eBay in a 5 month period, hence they can not track transactions preceding this period. Within this time period, however, repeat transactions, if they occurred at all, happened in a very short time period.
} 
$(+1)$, neutral $(0)$, or negative $(-1)$ score, along with a text comment ${ }^{14}$. eBay records and displays all of these comments, including the ID of the person making the comment. eBay also displays some summary statistics of users' feedback. The most prominently displayed summary statistic, which accompanies every mention of a user ID on eBay's web pages, is the number of positives that a particular user has received from other unique users, minus the number of negatives. ${ }^{15}$ eBay also computes and reports the number of positives/neutral/negatives that a seller has received in her lifetime, along with the last week, month and six months.

A prospective buyer on eBay therefore has access to considerable amount of information about the reputation of a seller. For instance, almost all of the feedback on eBay is positive. Resnick and Zeckhauser (2001) report that only $0.6 \%$ of feedback comments left on eBay by buyers about sellers was negative or neutral. One interpretation of this result is that most users are completely satisfied with their transaction. However, another interpretation is that users are hesitant to leave negative feedback for fear of retaliation. For instance, Cabral and Hortacsu (2003) report that a buyer who leaves a negative comment about a seller has a $40 \%$ chance of getting a negative back from the seller (whereas a neutral comment has a 10\% chance of being retaliated against). ${ }^{16}$ Another factor limiting the potential usefulness of feedback, reported by Resnick and Zeckhauser, is that feedback provision is an arguably costly activity that is completely voluntary, and that not all buyers (52.1\%) actually provide reviews about their sellers.

\subsection{Empirical Assessment of Feedback Mechanisms}

Do online reputation mechanisms work? The fact that we observe a large volume of trade on sites like eBay, Yahoo! and Amazon suggest may suggest that the answer to this

\footnotetext{
${ }^{14}$ Other auction sites such as Amazon allow for more nuanced feedback. Amazon, for example, utilizes a scale of 1 to 5 .

${ }^{15}$ In March 2003, eBay also began displaying the percentage of positive feedbacks along with the total score.

${ }^{16}$ Resnick and Zeckhauser (2001) also report in a smaller sample that in 18 out of 87 cases $(20 \%)$ where a buyer left negative feedback about a seller, the seller responded with a negative for the buyer. There is also the possibility that some buyers are more critical than others - although eBay allows users to observe the feedback that a user left about others, it does not provide summary statistics of left feedback - hence, making it quite costly for a prospective buyer to gauge the attitude of a particular commentor (other sites that provide user reviews, such as Amazon, allow readers of a comment to rate that comment on the basis of its usefulness).
} 
question is affirmative. However, there have also been a number of attempts to answer this question in a more direct manner, by estimating the market price of reputation in online auctions through hedonic regressions to estimate the response of market prices or stated willingness to pay to variation in measures of reputation.

Table 1, which is adapted from Resnick and Zeckhauser et al. (2003), summarizes these empirical studies. The first 10 studies on this list have used data on completed auction on eBay to run cross sectional hedonic regressions of the sale price or sale probabilities of similar objects on sellers' observable feedback characteristics. The (log) number of positive and negative comments is used as a right hand side variable in almost all of these studies. Some of these studies also attempted to account for nonlinearities in the functional relationship by putting in dummy variables for the existence of negatives, or dummy variables for different ranges of feedback. Some studies also explicitly recognize the truncation problem caused by auctions that did not end in a sale, and estimated a "probability of sale" equation either separately or jointly with the (log) price regression.

As can be seen in table 1, although the signs and statistical significance of the regression coefficients are mostly of the expected kind, the empirical results from these studies are not easily comparable, since some of them are reported in absolute terms, and some are reported in percentage terms. We should also note that the absolute number of feedback comments received by sellers follows a highly skewed distribution, reflecting a Gibrat's Law type effect. Given this, however, the starkest differences appear to be between sellers who have no feedback records, and those with a very large number of positive comments. For example, Melnik and Alm (2002) report that the difference between 452 and 1 positive comment is $\$ 1.59$ for $\$ 33$ items, implying a price premium of $5 \%$. Livingston's (2002) estimates imply a more than $10 \%$ price premium for sellers with more than 675 positive comments, as opposed to those with no feedback. Similarly, Kalyanam and McIntyre report that a seller with 3000 total feedback and 0 negatives is estimated to get $12 \%$ higher price than a seller with 10 total comments and 4 negatives. The presence of an up to $10-12 \%$ price premium between an "established" eBay seller (with hundreds or thousands of feedback comment) and a seller with no track record appears to be the most robust result among these studies, especially in light of the $8.1 \%$ 
price premium uncovered by a recent "field experiment" conducted by Resnick and Zeckhauser et al. (2003) to account for some of the more obvious confounding factors inherent in the hedonic regressions, which we shall discuss now.

The first confounding factor is that the estimate of reputation may be subject to an omitted variable bias. Since there is very little negative feedback, the number of positives is essentially equal to the number of transactions that a seller has completed on eBay. More experienced eBayers are on average more adept at constructing a well designed web page and responding to buyer questions. The work of Yin (2003) suggests that a well designed web page has a sizeable effect on final sales prices by reducing buyer uncertainty about the object for sale. As a result, more experienced sellers (as measured by positive feedback) will have higher sales prices for reasons that have nothing to do with reputation. ${ }^{17}$ Obviously, these factors could lead to biased estimates that overstate the market value of reputation scores obtained by sellers on eBay.

Ba and Pavlou (2002), Cabral and Hortacsu (2003), and Resnick and Zeckhauser et al. (2003) attempt to reduce this confounding factor by manipulating feedback indicators independently of other characteristics of auction listings. For example, Resnick and Zeckhauser et al. (2003) conducted a "field experiment" with the help of an established eBay seller (2000 positives, 1 negative), by selling matched pairs of postcards both under the seller's real name, and under newly created identities. The report that the established seller received, after correcting for non-sales, $8.1 \%$ higher prices than his newly formed identity. Ba and Pavlou (2002), on the other hand, asked a sample of eBay bidders to state their willingness to pay for eBay auction listings obtained from the web site, with the twist that seller feedback characteristics were manipulated by the experimenters. ${ }^{18}$ Cabral and Hortacsu (2003) exploited a change in eBay feedback reporting policy: as mentioned before, eBay began displaying the percentage of positives starting in March

\footnotetext{
${ }^{17}$ Standard models of dynamic industry equilibrium, such as Hopenhayn (1992) and Ericson and Pakes (1998) suggest that survival is positively correlated with measures of seller productivity.

${ }^{18}$ There may have been some other confounding factors that Resnick and Zeckhauser et al. might not have been able to remove with their experimental design. In particular, some buyers may have been repeat customers of the established seller ID, and some buyers may even have searched (or even had automatic watches) for sales by that seller, and not even looked at the matched listings from the new buyer. We thank Paul Resnick for pointing this out.
} 
2003. Cabral and Hortacsu (2003) run a hedonic regression where they interact different feedback summary statistics with a dummy variable for the policy change, and show that the negative correlation between prices and the percentage of negatives is larger after the policy change, whereas the correlation between prices and total feedback score, and the seller's age in days is smaller.

A second limitation of hedonic studies is that there is very little variation in certain independent variables, particularly negative feedback. For instance, in Houser and Wooders (2000), the maximum number of negative feedbacks in their data set is 12 . Similarly in Melnick and Alm (2002) the maximum number of negatives is 13. In the data set analyzed in Bajari and Hortacsu (2003), we found that only very large sellers with hundreds, if not thousands of positive feedbacks, had more than a handful of negative feedbacks. Obviously, it is hard to learn about the value of negative feedback when there is not much variation in this variable.

A third limitation is that the objects analyzed in the hedonic studies mentioned above are fairly inexpensive and standardized. Researchers prefer using standardized objects because it is fairly easy to collect book values, which are an important independent variable in hedonic regressions, for such items. Fairly inexpensive items are typically used because they are representative of the objects bought and sold in online markets.

However, it is arguable that the role of reputation is most important when a buyer is considering the purchase of a very expensive item of potentially dubious quality. When a buyer is purchasing a new, branded and standardized object (e.g. a new palm pilot) there is probably little uncertainty about the item up for sale. When the item is expensive, used and has uncertain quality, such as a hard to appraise antique, reputation might play a more important role. A buyer in such an auction might be reluctant to bid thousands of dollars when the seller has only limited feedback. However, such items have typically not been included in previous studies since it is difficult to construct appropriate controls for the value of such an item. In particular, book values for such items are probably not very meaningful.

A final limitation, which applies equally to both the hedonic regressions and the field experiment studies, is that it is difficult to interpret the "implicit prices" as buyer valuations or some other primitive economic object. In the applied econometric literature 
on hedonics, such as Rosen (1982) and Epple (1987), there is a fairly simple mapping from "implicit prices" to buyer preferences. The implicit price can typically be interpreted as the market price for a characteristic. Hence the implicit price is equal to the marginal rate of substitution between this characteristic and a composite commodity. This straightforward mapping breaks down when there is asymmetric information.

The winning bid in an auction is as a potentially complicated function of the underlying private information of all of the bidders. Only fairly stylized models of auctions would let the economist to directly interpret the coefficient on feedback as a marginal rate of substitution between reputation and a composite commodity. In the framework of Rezende (2003), if the economist makes the following assumptions, then the standard hedonic interpretation of implicit prices is valid:

1. There are private values and there is no asymmetric information among the bidders about the marginal value of the observed product characteristics.

2. There are no minimum bids or reserve prices.

3. All bidders are ex ante symmetric.

4. There are no product characteristics observed by the bidders but not the economist.

5. Entry is exogenous and a dummy variable for the number of bidders is included in the regression.

Clearly, these may be strong assumptions in many applications. In particular, a large fraction of online auctions use minimum bids or secret reserve prices. Also, it could be argued that uncertainty about quality naturally induces a common value component into the auction.

Many of the papers in the literature do not articulate a primitive set of assumptions under which the regression coefficients can be interpreted as a measure of buyers' willingness to pay for characteristics (such as reputation) or some other primitive economic parameter. While this limits the generality of the conclusions, it is nonetheless interesting to know the conditional mean of the sale price as a function of characteristics.

\subsection{Other Tests of the Theory.}

In addition to measuring the market price of a reputation, several other empirical observations have been made about feedback mechanisms. For example, Ba and Pavlou 
(2002) report that the impact of variation in feedback statistics is larger when the value of the object being sold is higher. This is consistent with economic intuition - the value of a reputation is more important for "big ticket" items. Jin and Kato (2002) and Ederington and Dewally (2003) find that for collectible objects for which professional grading is an option, sale prices of ungraded objects respond more to eBay's feedback statistics than graded objects. This is consistent with our conjecture above -- reputation is more important the less certain the buyer is about the quality of the item that is for sale.

Cabral and Hortacsu (2003) investigate whether sellers respond to the feedback mechanism. They use the feedback profiles of a cross section of active sellers to construct a backward-looking panel data set that tracks the comments received by the sellers. They find that, on average, the number of positive comments received by a seller until her first negative is much larger than the number of positive comments received between her first and second negatives. They investigate a number of alternative hypotheses for this phenomenon; in particular the possibility that buyers may be reluctant (possibly due to altruistic reasons) to be the first one to "tarnish" a seller's reputation. They find that buyers who place the first negative are not, on average, more likely to give negative comments than the buyers who gave the subsequent negatives. Moreover, they do not find an observable difference between the textual content of first vs. subsequent comments.

\subsection{Do Reputation Mechanisms Work?}

Given the various results in the literature, it is natural to attempt to reach a judgment as to whether reputation mechanisms achieve their purpose of reducing trading frictions on the Internet. The robust growth in the number of users and transactions on eBay could be regarded as a testament to the fact that fraud is not perceived as a huge deterrent on these markets. However, a number of authors express skepticism about the effectiveness of the feedback systems used on online auctions. For example, the study by Jin and Kato (2002), which we discussed in section 4, takes the stance that the observed patterns of trade can not be explained by rational buyers. The conclusion they reach in their study is that the prices ungraded cards were fetching on eBay were higher than could be rationalized by the frequency of fraudulent claims in their graded sample. They also found that although reputable sellers were less likely to make fraudulent claims and were 
also less likely to default or deliver counterfeits, the premium that buyers pay for reputation (after correcting for sales probability) is much lower than the premium that buyers pay for self claims. Hence they conclude that "In the current online market, at least some buyers drastically underestimate the risk of trading online" and that "...some buyers have difficulty interpreting the signals from seller reputation." The study by Resnick et al. (2003) also concludes with the statement that: "Nevertheless, it is hardly obvious that this reputation system would work sufficiently well to induce reliable seller behavior."

We believe that the jury is still out on the effectiveness of the reputation systems implemented by eBay and other online auction sites. There is still plenty of work to be done to understand how market participants utilize the information contained in the feedback forum system, and whether some of the seemingly obvious deficiencies of these systems, such as the free-riding problem inherent in the harvesting of user reviews and the presence of seller retaliation, are large enough to hamper the effectiveness of these systems. As in the analysis of the "late-bidding" phenomenon, perhaps controlled laboratory experiments can help shed more light into how different components of this complex problem work in isolation of each other. ${ }^{19}$

\subsection{Auction Design Insights from Online Auctions}

Perhaps the most central question that auction theorists try to answer is "What kind of an auction should I use to sell my goods?" Interestingly, perhaps the most central result in auction theory is one that says that most well-known auction rules lead to very similar results: this is the revenue equivalence theorem (RET), first stated by Vickrey (1962), and later proved by Myerson (1981), Riley and Samuelson (1981). The theorem states that when buyers possess independent private values, two auction formats that lead to the same allocation in equilibrium yield the same expected revenue for the seller (Krishna $(2002))^{20}$

\footnotetext{
${ }^{19}$ An initial attempt in this direction is a laboratory experiment by Bolton, Katok and Ockenfels (2003), which shows that the free-riding problem maybe an important deficiency of current reputation systems.

${ }^{20}$ The theorem extends in several interesting directions. For example, Riley and Samuelson (1981) showed that RET holds when there are multiple units are being sold and each bidder demands a single unit. Myerson (1981) showed that it extends to the case where buyers valuations are interdependent, with the condition that private information is independently distributed across bidders. Harstad (1990) showed that the result extends to the case where the number of bidders in the auction is uncertain.
} 
This fundamental result of auction theory has been the subject of a large body of experimental research, in which bidders are assigned valuations and asked to bid across different auction formats. ${ }^{21}$ However, online auctions can also yield empirical insights regarding the validity of the revenue equivalence theorem, especially due to the fact that it is relatively easy to use online auction sites for field experiments.

A good example for such a field experiment is by Lucking-Reiley (1999). In his experiment, Lucking-Reiley wanted to test: 1) the strategic, hence revenue, equivalence between the descending price (Dutch) and sealed-bid first price auction, and 2) the strategic equivalence, and hence revenue equivalence (under private values) between the second price and English auctions. We should note that previous studies using laboratory experiments, by Coppinger et al. (1980), and Cox et al. (1982) rejected the strategic equivalence of first-price auctions with descending auctions, and reported higher prices in first-price auctions than Dutch auctions, with Dutch auctions yielding 5\% lower revenues on average. Similarly, Kagel, Harstad and Levin (1987) report the failure of strategic equivalence of the second-price and English auctions in the laboratory setting. In particular, they report a tendency for subjects to bid above their valuations in the second price auction, whereas they rapidly converge to bidding their values in the English auction, yielding $11 \%$ higher revenue for the second-price auction.

Lucking-Reiley's experiment used different auction procedures to sell trading cards for the role-playing game, Magic: The Gathering, on an Internet newsgroup that was organized as an online marketplace for enthusiasts in "pre-eBay" days. Lucking-Reiley invited participants to his auctions using e-mail invitations and postings on the newsgroup. To minimize differences across participants' distribution of values for the auctioned cards, Lucking-Reiley used a "matched-pair" design. For example, in the comparison of first-price and Dutch auctions, Lucking-Reiley first auctioned a set of cards using the first price auction; a few days after his first set of auctions ended, he sold an identical set of cards using a Dutch auction. To account for temporal differences in bidders' demand for these cards, Lucking-Reiley repeated the paired experiment about 4

\footnotetext{
${ }^{21}$ For a comprehensive survey, see Kagel and Roth (1995), Chapter 7.
} 
months later, but this time selling the first set using Dutch auctions, and the second set using first-price auctions.

Lucking-Reiley found that Dutch auctions yielded 30\% higher average revenue than the first-price auctions, in contrast with previous findings from laboratory experiments. ${ }^{22}$ In the second-price vs. English auction experiment, Reiley found that the auction formats yielded statistically similar revenues, in contrast to experimental findings of over-bidding in second price auctions.

What explains the differences across Lucking-Reiley's results and results from laboratory experiments? Several explanations followed immediately from the methodological differences outlined above. First of all, as Lucking-Reiley notes, his field experiment can not control for the entry decisions of the bidders: he reports that Dutch auctions attracted almost double the number of bidders as his first-price auctions, and it is not hard to see that an increase in the number of bidders would increase revenues. The causes of the higher participation in the Dutch auction remains a mystery: LuckingReiley argues that this is not solely due to the "novelty" of the Dutch auction mechanism, since market participants had been exposed to Dutch auctions before. One wonders, however, whether with a 40 cent price differential on average, a "taste for novelty" effect may persevere. ${ }^{23}$

Second, Lucking-Reiley's experiment can not control for the informational structure of the auction. In the laboratory, the researcher can choose whether to run a common value or a private value auction; however, Lucking-Reiley can not pre-determine whether bidders will regard his trading cards as private value or common value objects. This may affect Reiley's interpretation of his second-price vs. ascending auction results: in a common value environment, the second-price auction is predicted to yield lower average revenues. This factor, compounded with the experimentally reported "bias" of the bidders to overbid, may result in the observed revenue equivalence result.

\footnotetext{
${ }^{22}$ Note that the absolute revenue differences are comparable across Reiley's experiment and Cox, Roberson and Smith's (1982) experimental result - about 40 cents in each case, though statistically significant.

${ }^{23}$ Lucking-Reiley also discusses whether the speed at which prices decline in Dutch auctions may have led to a difference between his results and laboratory results - in his field experiment, prices declined much slower than in the laboratory. Interestingly, Kwasnica and Katok (2003) find, in a laboratory setting, that slower price declines in Dutch auctions led to increased revenues as compared to sealed-bid auctions, suggesting that bidder impatience may have played a role in the field experiment setting.
} 
On the other hand, one may think that the online marketplace utilized by LuckingReiley is populated by "veterans" of previous auctions, who are experienced enough not to "overbid" in a second-price auction - hence the theoretical prediction of revenue equivalence is more likely to be borne out in the field than in the laboratory. LuckingReiley briefly mentions this possibility; though more direct evidence comes from elsewhere. In a very recent paper, Garratt, Walker, and Wooders (2002) invited experienced bidders on eBay to take part in second-price auction experiments conducted in a laboratory setup. In contrast to previous experimental findings, Garratt, Walker, and Wooders found that bidders experienced on eBay do not overbid in second-price private value auctions, and, very often, give the correct reasoning to their action. Hence, fieldexperiments conducted on online auction sites may indeed provide a more qualified subject pool for auction experiments.

Another argument for the use field experiment methodology, as pointed out by Lucking-Reiley, is that in practical settings where a seller is trying to assess the proper auction mechanism to use, controls for endogenous entry decisions and on the informational environment will typically not be present. For example, the fact that a Dutch auction may lead to higher bidder participation maybe an outcome variable of interest to a seller considering switching to this auction format; especially since it leads to higher revenues. Hence, Lucking-Reiley argues that for practical or policy applications, results of field experiments may provide more insights regarding the outcome of a possible policy change.

We should also note the comparison between the "field experiment" approach to what an econometrician could have done using bidding data from an auction site on which different auction formats are utilized. As Lucking-Reiley notes, a non-experimental analysis of whether a first-price or a second-price auction yields higher revenues may have to worry about why some auctions were conducted using a first-price auction, and others using a second-price auction. ${ }^{24}$ On the other hand, we should note that the field experimentation methodology, as used by Lucking-Reiley, can only shed light onto partial-equilibrium responses to changes in mechanism design. For example, his finding

\footnotetext{
${ }^{24}$ Lucking-Reiley quotes Hansen's (1985) finding of systematic differences in timber lots sold using sealed-bid vs. ascending auction by the U.S. Forest Service.
} 
that Dutch auctions yield 30\% higher revenues than first-price auctions may not apply if every seller on an auction site decides to use a Dutch auction as opposed to a first-price auction. $^{25}$

Whatever its pros and cons, Lucking-Reiley's paper is a good example of how online auction sites can be used as a laboratory for creative field experiments. Last, but not least, we should point out that a very important advantage of this "field laboratory" is that it was relatively inexpensive to use: Lucking-Reiley's experiment had an initial cost of $\$ 2,000$ to buy about 400 trading cards, which he claims to have recouped with a profit (in addition to a published thesis chapter) after selling them. Moreover, at the cost of some lack of customizability, online auction sites make it easy for the researcher to set-up and track experiments; instead of requiring her to spend significant amount of programming time to write software for her own experiments.

\subsection{Revealed Preference for Ascending Auctions?}

Not all empirical insights from online auction sites are the result of field experiments or structural econometric models. A casual observer of online auction sites will immediately observe the following pattern: all three major online auction sites (eBay, Yahoo!, Amazon) use the proxy-bidding format (albeit with differing ending rules, as discussed in section 3). In a much more comprehensive survey, Lucking-Reiley (2000a) found that 121 of the 142 Internet auction sites he surveyed in 1998 used an ascending auction format. 7 sites used a first-price sealed-bid auction and 8 used a second-price sealed-bid auction. $^{26}$

What is so special about the proxy-bidding mechanism, or open-ascending auction formats in general? Note that a strict application of the revenue equivalence theorem here suggests that buyers, sellers, and the site operator (who takes a commission out of the transaction) alike should be indifferent between open-ascending auctions and sealed-bid auctions. Lucking-Reiley (2000a) suggests that, on sites like eBay, where there are many sellers trying to sell the same type of good simultaneously, bidders will have an easier time deciding which auction to bid on.

\footnotetext{
${ }^{25}$ Lucking-Reiley notes that the marketplace was active enough that his 80 auctions would not have a "market-wide" impact.

${ }^{26}$ We should note that although first-price sealed bid auctions are quite common in offline contexts such as procurement, second-price auctions were quite rare. For a historical account of the use of second-price or Vickrey auctions, see Lucking-Reiley (2000b).
} 
Peters and Severinov (2002) make this intuition more rigorous. In an independent private values setting where there are many simultaneous English auctions of the same good, they show that the following is a perfect Bayesian equilibrium strategy for a bidder: place a bid in the auction with the lowest current price and raise your bid as slowly as possible, until you hit your valuation. ${ }^{27}$ The resulting equilibrium will then lead to all bidders paying a uniform "market-clearing" price, which is equal to the valuation of the highest losing bidder. Thus, there is no need for an active "market-maker" to solicit bids and offers from buyers and sellers and match them using a rule such as Walrasian market-clearing - the decentralized equilibrium leads to an ex-post efficient allocation (one in which no buyer regrets the price at which she bought). Observe that although Peters and Severinov's prescribed equilibrium strategy requires bidders to be very attentive (or utilize the help of automated bidding software, versions of which are available on the Internet), the decision problem of a bidder facing multiple simultaneous sealed-bid auctions is considerably more complicated, leading, in many cases, to randomized entry decisions. ${ }^{28}$

A more standard explanation for the prevalence of open-ascending auction formats on the Internet can be given based on the results of Milgrom and Weber (1982). As discussed in section 4 , in many of the auctions conducted on these sites, a common value element may be present. As shown by Milgrom and Weber (1982), the open-ascending English auction yields higher expected revenues than its sealed-bid counterparts - loosely due to the fact that a bidder in the English auction has to worry less about suffering from a "winner's curse," and hence does not strategically shade her bid as much. This does not automatically mean, however, that ex-ante, bidders expect to gain less surplus from participating in an English auction as opposed to a sealed-bid auction. The English auction can yield more revenue to the seller because more information is revealed during this auction, as opposed to in a sealed-bid auction. Left to their devices, bidders in a sealed-bid auction might have chosen to buy some of this information. Hence, from the perspective of sellers, buyers, and the site operator alike, the use of an open-ascending

\footnotetext{
${ }^{27}$ We should note that in Peters and Severinov's model, all auctions end at the same time.

${ }^{28}$ This is not to say that there aren't mixed strategy equilibria in the game constructed by Peters and Severinov; however, in many plausible versions of the simultaneous sealed-bid auction game, there are no symmetric pure strategy equilibria.
} 
auction format such as the English auction yields benefits to all: the sellers gains higher revenues, the buyers avoid the winner's curse, and the site-operator gains higher commissions. $^{29}$

Sealed-bid auctions may have advantages as well. Robinson (1985) and McAfee and McMillan (1992) have suggested that collusion maybe more difficult to sustain in sealedbid first price auctions as opposed to English auctions. This may explain why sealed-bid auctions are very prevalent in procurement contexts, where there is repeated interaction within a small group bidding firms. On Internet auction sites, free-entry, geographic dispersion, and anonymity of bidders may make collusion much harder to sustain.

Yet another strand of explanation for why bidders and sellers may have preferences over ascending vs. sealed bid auctions is based on risk aversion. As shown by Holt (1980) and Matthews (1987), revenue equivalence of sealed-bid first-price and English auctions breaks down if bidders are risk averse. In particular, Matthews (1987) shows that bidders with DARA (decreasing absolute risk aversion) preferences would prefer the English auction, since equilibrium bids in the sealed-bid first price auction are higher than in the English auction. However, we should note that it trivially follows that in this case the seller would prefer the sealed-bid first price auction over the English auction, hence it is not clear whether a "demand-side" preference might be enough to explain the prevalence of ascending auctions.

To investigate bidders' preferences over different auction mechanisms, IvanovaStenzel and Salmon (2003) ran an experiment in which they allowed bidders to choose, for an entry fee, between a sealed-bid first-price auction and an English auction. ${ }^{30}$ The authors report that when entry prices for the two auction formats are the same, the subjects overwhelmingly preferred the English auction. By varying the entry prices across the formats, the authors attempted to measure bidders' willingness to pay for the English auction. The observed willingness-to-pay for the English auction, however, was much higher than the profit differential implied by the risk-aversion explanation, which

\footnotetext{
${ }^{29}$ We should note, however, that the use of a hard-deadline ending rule can nullify this benefit of using an ascending auction, since rampant sniping leads to much less information revelation during the auction.

${ }^{30}$ The experiments were independent private value auctions, with the distribution of valuations kept constant across auction formats. The subjects did not observe their valuations prior to choosing the auction format to participate in.
} 
led the authors to conclude that there is a yet unexplained "demand" component that drives bidders' revealed preference for the English auction.

We believe that Ivanova-Stenzel and Salmon's (2003) study is an important first-step towards understanding the economic forces shaping the demand for different types of trading mechanisms. Auction theory is almost exclusively couched in a "partial equilibrium" framework, where competition between different trading mechanisms is seldom studied. ${ }^{31}$ Studying demand and supply patterns on the Internet may prove quite fruitful in future research in this area, since data on prices and quantities is relatively easy to obtain, and wide variation across markets/types of goods can be observed.

\subsection{Reserve prices}

Auction design is not only about choosing the auction format. As shown by Myerson (1981), even when the revenue equivalence theorem renders the choice of format irrelevant, a seller may significantly increase her revenues by optimally setting a (publicly observable) reserve price, or, equivalently, a minimum bid.

A look at sellers' practices of setting reserve prices reveals an interesting regularity: as noted by Bajari and Hortacsu (2003), many sellers on eBay, especially those selling higher value items, choose to keep their reserve prices secret, as opposed to publicly announcing it. This immediately brings up the question: "When, if ever, should one use a secret reserve price, as opposed to a publicly observable minimum bid?"

Auction theory has been relatively silent regarding this question, with two noteable exceptions. Li and Tan (2000) show that with risk-aversion, secret reserve prices may increase the auctioneer's revenue in an independent private value first-price auction, but in second-price and English auction, regardless of the bidders' risk preferences, the auctioneer should be indifferent between setting a secret vs. observable reserve price. Vincent (1995) provides an example in which setting a secret reserve price in an interdependent value second-price auction can increase the auctioneer's revenues. Vincent's basic intuition is that the minimum bid censors some bidders, and the inference drawn by participants in the auction from this censored distribution may lead to lower bids than inference from the uncensored distribution.

\footnotetext{
${ }^{31}$ Two notable exceptions are by McAfee (1993) and Peters and Severinov (1997).
} 
Given the above theoretical results, especially that of Vincent (1995), Bajari and Hortacsu (2003), estimate bidders' common value and private signal distributions in a symmetric common value second-price auction model of eBay coin auctions, and use these parameter values to numerically compute optimal minimum bid and secret reserve price levels, to compare the revenues expected from these two pricing policies. They find that, at its optimal level, a secret reserve price can yield the seller $1 \%$ higher expected revenue.

Katkar and Lucking-Reiley (2000) question the validity of the behavioral assumptions used in Bajari and Hortacsu's (2003) structural econometric model, and attempt to answer the same question using a field experiment. In their experiment, the authors bought and sold 50 matched pairs of Pokemon trading cards on eBay, auctioning one card in the pair using a publicly announced minimum bid, and the other using a secret reserve price that set equal to the minimum bid. They found that the secret reserve price auctions yielded 60 cents less revenue on average (average card value was approximately \$7). They also reported that secret reserve price auctions were less likely to end in a sale.

Although Katkar and Lucking-Reiley (2000) have a valid point in questioning the structural econometric approach of Bajari and Hortacsu (2003) especially with regards to its imposition of fully rational behavior by the bidders, the field experiment approach they utilize is also subject to important caveats. For example, an important feature of Katkar and Lucking-Reiley's experiment is that the minimum bids and the secret reserves were assigned arbitrarily, and were kept constant across treatments. However, under the assumption of seller rationality, a more appropriate comparison should be between the ex-ante revenue maximizing values of the minimum bid and the secret reserve price, which might not necessarily be the same. Unfortunately, deriving ex-ante revenue maximizing values of the choice variables above is actually not a very straightforward exercise, since, as first derived by Myerson (1981), a calculation of the revenue maximizing minimum bid depends on the distribution of bidders' valuations - which must be estimated from bidding data.

The previous discussion underlines some of the subtleties underlying the analysis and interpretation of experimental or non-experimental data from online auction sites for the purpose of evaluating mechanism design alternatives. The treatment effects estimated 
using a randomized field experiment such as Katkar and Lucking-Reiley (2000) may not always have a clear interpretation within the context of a theoretical model. Structural econometric models, as utilized in Bajari and Hortacsu (2003), have the advantage that their estimates can be readily interpreted within the context of a theoretical model, but their results may not always be robust to specification error, or problems associated with the non-experimental nature of the data. The user of either approach should be very clear about the shortcomings of the respective methods; and, if possible, use the two methodologies in a complementary manner.

Coming back to the question of whether empirical studies have taught us anything about the use of reserve prices, we should note that both of the papers surveyed here are unable to provide a very satisfactory answer to the question "if one reserve price mechanism revenue-dominates the other, why do sellers persist in using the dominated mechanism?" Katkar and Reiley (2000) quote that an additional "benefit" of the secret reserve price strategy that their experiment does not account for - by setting a very high secret reserve, a seller may first screen out the bidders with the highest valuations for the object, and later contact them away from eBay to run a private transaction for which he does not have to pay commission to eBay. On the flip-side, Bajari and Hortacsu (2003) mention an additional "cost" of using a secret reserve price auction: some buyers, especially new participants who do not quite understand the rules of eBay, may get angry upon not winning an auction due to a secret reserve and place a negative comment on the seller's record. However, neither paper provides a satisfactory reconciliation of these various costs and benefits to explain the patterns of usage of different reserve price strategies on eBay. We believe this may be an interesting avenue for future research.

\subsection{Endogenous Entry decisions of bidders}

Another theoretical question that has been put under empirical scrutiny by both field experimentation and structural econometric modeling is the endogenous entry decisions of bidders. As noted by Levin and Smith (1994), most theoretical revenue comparisons between auction formats take the number of participants in the auction as given. However, even on eBay, bidders may incur costs to bid in an auction, albeit due to the time she spends searching for the right auction, or to the time she spends watching the bidding come to a close (though some may also derive enjoyment from the process). 
Hence, a more realistic model of bidding in an auction should endogenize the number of participants, where the bidders weigh the expected benefit from winning the auction against the cost of participating. This, in turn, means that auction mechanisms that offer different expected surpluses to the bidders will attract different number of bidders; and hence the revenues generated two auction designs can not be compared under the assumption that the same number of bidders participate in both. In fact, Levin and Smith (1994) argue that this may lead to a more general revenue equivalence principle, since expected payments to bidders should be equalized across two auction mechanisms when the choice is present, the expected revenues of the sellers should also equalize.

The analysis of online auctions suggests that entry costs, and hence the endogenous entry decisions of bidders, are indeed quite important, and should be taken into account when modeling the performance of alternative trading rules in such environments. Lucking-Reiley (1999) once again uses the field experiment method to assess the entry costs of bidders on online auctions. He notes that when he auctioned several trading cards simultaneously, with zero minimum bids on each, very few bidders placed bids on every item, and argues that this is consistent with the presence of bidding costs. He also finds, not very surprisingly, that higher minimum bids on otherwise comparable auctions resulted in fewer participants (a finding also corroborated by correlations reported by McAfee, Vincent and Quan (2002), Bajari and Hortacsu (2003), Lucking-Reiley, Bryan, Prasad and Reeves (2000)). ${ }^{32}$

\subsection{Conclusion.}

Online auctions are the subject of a rapidly growing body of research. Interest in these markets stems from three factors. First, online auctions are an inexpensive source for high quality data. In empirical economics, our data is often a very incomplete

\footnotetext{
32 A quantification of the magnitude of these entry costs, however, requires the imposition of a model of entry to calculate the trade-off between the expected benefit from participation and the cost of bidding. Bajari and Hortacsu (2003) use their structural model to estimate the implied cost of bidding on eBay coin auctions to be around \$3; a significant cost, given that the average object in their sample was worth $\$ 47$. It is interesting to note that several Internet services like eSnipe and AuctionWatch, along with eBay itself, have invested into developing technologies to make it easier for bidders to search listed auctions, to monitor progress in simultaneous auctions by creating watchlists, and to place "snipe" bids in the auctions they are participating.
} 
representation of the markets that we study. Often, the researcher cannot measure important product characteristics that determine consumers' choices. Also, we cannot always observe all of the relevant actions of buyers and sellers. In online auctions, the economist is able to observe almost all of the product information that is available to the bidders. Also, the actions of buyers and sellers are recorded in minute detail. The exact time and amount of the proxy bids and the sellers' reserve price policies can easily be downloaded. Second, online auctions are a natural testing ground for auction theory. A substantial body of economic theory studies how to optimally design an auction. In online auctions, we can see how the mechanisms examined in theory perform in the field. Given the easy access to high quality data and constant evolution of these trading mechanisms, we predict that online auctions will continue to generate interest among many researchers. 


\section{Bibliography.}

Athey, S. and Haile, P. "Identification in Standard Auction Models," Econometrica, 70 (6), November 2002, pp. 2107-2140.

Ariely, D., Ockenfels, A. and Roth, A. "An Experimental Analysis of Ending Rules in Internet Auctions." Working paper, Harvard Business School 2003.

Ba, S. and Pavlou, P.. "Evidence of the Effect of Trust Building Technology in Electronic Markets: Price Premiums and Buyer Behavior," MIS Quarterly, 26(3), 2002 pp. 243-268.

Bajari, P. and Hortacsu, A. "The Winner's Curse, Reserve Prices and Endogenous Entry: Empirical Insights from eBay Auctions", Rand Journal of Economics, Vol. 3, No. 2, pp. 329-355.

Bulow, J. and Roberts, J. “The simple economics of optimal auctions.” Journal of Political Economy, 97(5), pp.1060-1090, 1989.

Cabral, L. and Hortacsu, A. "Dynamics of Seller Reputation: Theory and Evidence from eBay," mimeo 2003.

Camerer, C. "Can Asset Markets Be Manipulated? A Field Experiment With Racetrack Betting." Journal of Political Economy, 106(3), 1998, pp. 457-482.

Coppinger, V., Smith, V. and J. Titus. "Incentives and Behavior in English, Dutch and sealed-bid auctions," Economic Inquiry, 43, 1980, 1-22.

Cohen, A. The Perfect Store: Inside eBay. Little Brown \& Company, 1st edition (June 2002).

Cox, J.C., Roberson, B. and Smith, V. "Theory and Behavior of single object auctions," in Research in Experimental Economics, 1982, Vernon L. Smith, ed., Greenwich, Conn.:JAI Press.

Dellarocas, C. "The Digitization of Word-of-Mouth: Promise and Challenges of Online Reputation Mechanisms," 2002, forthcoming in Management Science.

Dewan, S. and Hsu, V. "Trust in Electronic Markets: Price Discovery in Generalist Versus Specialty Online Auctions," mimeo 2001.

Eaton, D. H. "Valuing Information: Evidence from Guitar Auction on eBay," mimeo 2002.

Ederington, L. H. and M. Dewally. "A Comparison of Reputation, Certification, Warranties, and Information Disclosure as Remedies for Information Asymmetries: Lessons from the On-Line Comic Book Market," working paper 2003.

Elyakime, B., Laffont, J.J., Loisel, P., and Q. Vuong. 1994. "First price sealed bid auctions with secret reservation price," Annales d'Economie et Statistique, 34, 115-141.

Garratt R., Walker, M., and J. Wooders. "Experienced Bidders in Online Second-Price Auctions." University of Arizona working paper 2002. 
Haile, P., Hong, H., and Shum, M. "Nonparametric Tests for Common Values in First-Price Auctions." 2000 Mimeo.

Hansen, R. "Sealed Bid Versus Open Auctions: The Evidence," Economic Inquiry, 24, 1986, pp. 125-14.

Harstad, R., Kagel, J. and D. Levin. "Equilibrium Bid Functions for Auctions with an Uncertain Number of Bidders," Economics Letters, 33, 1990, pp. 35-40.

Hasker, K., Gonzalez, R. and Sickles, R. "An Analysis of Strategic Behavior and Consumer Surplus in eBay Auctions”, Rice University Working Paper 2003.

Holt, C. "Competitive Bidding for Contracts under Alternative Auction Procedures," Journal of Political Economy, 88, 1980, pp. 433-45.

Houser, D. and J. Wooders. "Reputation in Auctions: Theory and Evidence from eBay," working paper 2003.

Ivanova-Stenzel, R. and T. Salmon. "Bidder Preferences Among Auction Institutions," 2003 forthcoming in Economic Inquiry.

Jin, G. Z. and A. Kato. "Blind Trust Online: Experimental Evidence from Baseball Cards," University of Maryland working paper 2002.

Kagel, J. H., Harstad R. M., and D. Levin. "Information Impact and Allocation Rules in Auctions with Affiliated Private Values: A Laboratory Study," Econometrica, 55, 1987, pp. 1275-1304.

Kagel, J. and A. Roth (eds.), The Handbook of Experimental Economics, Princeton University Press, 1995, Princeton, NJ.

Kalyanam, K. and McIntyre, S. "Returns to Reputation in Online Auction Markets," mimeo 2001.

Katok, E. and Kwasnica, A. "Time is Money: The Effect of Clock Speed and Seller's Revenue in Dutch Auctions," Penn State University working paper, May 2002.

Katkar, R. and Lucking-Reiley, D. "Public Versus Secret Reserve Prices in eBay Auctions: Results from a Pokémon Field Experiment," University of Arizona working paper 2000.

Kazumori, E. and McMillan, J. "Selling Online Versus Live”, Stanford GSB and CalTech working paper 2003.

Krishna, V. Auction Theory, Academic Press, 2002, San Diego, CA.

Ku, G., Malhotra, D. and Murnighan, J. "Competitive Arousal in Live and Internet Auctions", Working Paper, Kellogg Graduate School of Management, Northwestern University.

Levin, D. and Smith, J. L. "Equilibrium in Auctions with Entry," American Economic Review, 54, 1994, pp. 585-99.

Li, Huagang and G. Tan. "Hidden Reserve Prices with Risk Averse Bidders." mimeo 2000. 
Livingston, J. "How Valuable is a Good Reputation? A Sample Selection Model of Internet Auctions." mimeo 2002.

Lucking-Reiley, D. "Using Field Experiments to Test Equivalence Between Auction Formats: Magic on the Internet," American Economic Review, 89, no. 5, 1999, pp. 1063-1080.

Lucking-Reiley, David. "Vickrey Auctions in Practice: From Nineteenth-Century Philately to Twenty-First-Century E-Commerce," Journal of Economic Perspectives, Summer 2000, vol. 14, no. 3, pp. 183-192.

Lucking-Reiley, D. "Experimental Evidence on the Endogenous Entry of Bidders in Internet Auctions." Working paper.

Lucking-Reiley, D., Bryan, D., Prasad, N., and D. Reeves. "Pennies from eBay: the Determinants of Price in Online Auctions," 2000 University of Arizona working paper.

Lucking-Reiley, D."Auctions on the Internet: What's Being Auctioned, and How?" Journal of Industrial Economics, September 2000, vol. 48, no. 3, pp. 227-252.

Matthews, S. "Comparing Auctions for Risk Averse Buyers: A Buyer's Point of View," Econometrica, 55, 1995, pp. 633-46.

McAfee, P., and J. McMillan. "Bidding Rings," American Economic Review, 82, 1992, pp. 579599.

McAfee, R.P. "Mechanism Design by Competing Sellers," Econometrica, 61, 1993, pp. 12811312.

McAfee, R. P., D. Quan, and D. Vincent. "How to Set Minimum Acceptable Bids, with an Application to Real Estate Auctions," Journal of Industrial Economics, 50, 2002, pp. 391-416.

McDonald, C. G., Slawson, V. C. "Reputation in an Internet Auction Market," Economic Inquiry, 40, 2002, pp. 633-650.

Melnick, M. I. and J. Alm. "Does A Seller's eCommerce Reputation Matter? Evidence from eBay Auctions." Journal of Industrial Economics, 50, 2002, pp. 337-50.

Milgrom, P. and R. Weber. "A Theory of Auctions and Competitive Bidding," Econometrica, 50, 1982, pp. 1089-1122.

Morgan, J. and Hossain, T. "A Test of the Revenue Equivalence Theorem using Field Experiments on eBay,” Haas Business School Working Paper 2003.

Myerson, R. “Optimal Auction Design.” Mathematics of Operation Research, 6, 1981, pp. 58-73.

Ockenfels, A. and Roth, A., "Last-Minute Bidding and the Rules for Ending Second-Price Auctions: Evidence from eBay and Amazon Auctions on the Internet", American Economic Review, 2002a, vol. 92, issue 4, pp. 1093-1103. 
Ockenfels, A. and Roth A. "Late Bidding in Second Price Internet Auctions: Theory and Evidence Concerning the Rules for Ending the Auctions," 2002b forthcoming Games and Economic Behavior.

Paarsch, H. "Deciding Between the Common and Private Value Paradigms in Empirical Models of Auctions," Journal of Econometrics, 1992, 51, pp. 191-215.

Park, S. "Website Usage and Seller's Listing in Internet Auctions," SUNY Stony Brook working paper, September 2002.

Peters, M. and S. Severinov. "Competition Among Sellers Who Offer Auctions Instead of Prices," Journal of Economic Theory, 75, 1997, pp. 141-79.

Peters, M. and S. Severinov. "Internet Auctions with Many Traders," University of Wisconsin working paper 2001.

Rasmusen, Eric, "Strategic Implications of Uncertainty Over One's Own Private Value in Auctions," Indiana University Working Paper 2001.

Resnick, P., Zeckhauser, R., Swanson, J. and K. Lockwood. "The Value of Reputation on eBay: A Controlled Experiment," Harvard Kennedy School working paper 2003.

Resnick, P. and Zeckhauser, R. "Trust Among Strangers in Internet Transactions: Empirical Analysis of eBay's Reputation System," Harvard Kennedy School working paper 2001.

Rezende, L. “Auction Econometrics by Least Squares,” 2003 mimeo.

Riley, J. and W. Samuelson. “Optimal Auctions.” American Economic Review, 71, 1981, pp. 38192.

Robinson, M. "Collusion and the Choice of Auction," Rand Journal of Economics, 16, 1985, pp. 141-45.

Schindler, J. "Late Bidding on the Internet", 2003 mimeo.

Vickrey, W. "Counterspeculation, Auctions and Competitive Sealed Tenders," Journal of Finance, 16, 1961, pp. 8-37.

Vincent, D. "Bidding Off The Wall: Why Reserve Prices May be Kept Secret," Journal of Economic Theory, 65, 1995, pp. 75-84.

Wang, J. “Is Last Minute Bidding Bad”, UCLA Working Paper 2003.

Wilcox, R. T. "Experts and Amateurs: The Role of Experience in Internet Auctions", Marketing Letters, November 2000, 11(4), pp. 363-74.

Wilson, R. “A Bidding Model of Perfect Competition." Review of Economic Studies, Vol. 44, 1977, pp. 511-518.

Wolverton, Troy. “eBay Users Miffed by New Fees,” CNET News.com, August 20, 1999. 
Yin, P. "Information Dispersion and Auction Prices", Harvard Business School Working Paper 2003. 


\begin{tabular}{|c|c|c|c|c|c|c|}
\hline \multicolumn{6}{|c|}{ Table 1: Empirical Studies on the Val } & \\
\hline Source & Items Sold & $\begin{array}{l}\text { Mean } \\
\text { price }\end{array}$ & Type of Study & $\begin{array}{l}\text { Covariates ("?" } \\
\text { indicates dummy } \\
\text { variable) }\end{array}$ & $\begin{array}{l}\text { Modeling } \\
\text { Specification }\end{array}$ & $\begin{array}{l}\text { Results regarding } \\
\text { market value of } \\
\text { reputation }\end{array}$ \\
\hline $\begin{array}{l}\text { (Dewan and Hsu, } \\
\text { 2001) }\end{array}$ & Collectible stamps & $\$ 37$ & $\begin{array}{l}\text { hedonic regression, } \\
\text { compare auction prices } \\
\text { on eBay with specialty } \\
\text { site (Michael } \\
\text { Rogers,Inc) }\end{array}$ & $\begin{array}{l}\text { book value; international } \\
\text { transaction?; number of } \\
\text { bids; full set?; close on } \\
\text { weekend?; buyer's net } \\
\text { rating }\end{array}$ & $\begin{array}{l}\text { OLS for sold items only; } \\
\ln \text { (price) vs. } \ln \text { (positive- } \\
\text { negative) }\end{array}$ & $\begin{array}{l}20 \text { additional seller rating } \\
\text { points translate into a } 5 \text { cent } \\
\text { increase in auction price on } \\
\text { eBay. Average bids higher on } \\
\text { specialty site, but seller } \\
\text { revenues on specialty site } \\
\text { (after } 15 \% \text { commission) are } \\
\text { same with revenues on eBay. }\end{array}$ \\
\hline (Eaton, 2002) & Electric guitars & $\$ 1,621$ & hedonic regression & $\begin{array}{l}\text { guitar type; credit card?; } \\
\text { escrow?; pictures?; } \\
\text { interaction terms }\end{array}$ & $\begin{array}{l}\text { reduced form, logit on } \\
\text { probability of sale, OLS on } \\
\text { items sold: positives } \\
\text { (number); negatives } \\
\text { (dummy or number) }\end{array}$ & $\begin{array}{l}\text { No robust statistically } \\
\text { significant relation between } \\
\text { negative feedback and } \\
\text { probability of sale and price of } \\
\text { sold items }\end{array}$ \\
\hline $\begin{array}{l}\text { (Houser and } \\
\text { Wooders, 2000) }\end{array}$ & Pentium chips & $\$ 244$ & hedonic regression & $\begin{array}{l}\text { auction length, credit card, } \\
\text { book value, used, } \\
\text { processor type }\end{array}$ & $\begin{array}{l}\text { model of bidder } \\
\text { distributions based on } \\
\text { private values motivates } \\
\text { reduced-form GLS (on } \\
\text { sold items only), with } \\
\text { expectation of more } \\
\text { bidders for longer } \\
\text { auctions; ln(high-bid) vs. } \\
\ln (\text { pos), ln(non-positive) }\end{array}$ & $\begin{array}{l}10 \% \text { increase in positive } \\
\text { feedback increases price } \\
0.17 \% ; 10 \% \text { increase in } \\
\text { negative feedback reduces it } \\
\text { by } 0.24 \% \text {. Increasing positive } \\
\text { comments from } 0 \text { to } 15 \\
\text { increase price by } 5 \% \text {, or } \$ 12 .\end{array}$ \\
\hline $\begin{array}{l}\text { (Jin and Kato, } \\
2002)\end{array}$ & Sports trading cards & $\$ 166$ & hedonic regression & $\begin{array}{l}\text { same as (Melnik and Alm, } \\
\text { 2002) }\end{array}$ & $\begin{array}{l}\text { probit predicts probability } \\
\text { of sale; OLS for sold } \\
\text { items, } \ln (\text { price/book) vs. } \\
\text { ln(net score), has } \\
\text { negatives? }\end{array}$ & $\begin{array}{l}\text { Positive feedback increases } \\
\text { probability of sale; negative } \\
\text { decreases probability of sale } \\
\text { unless card is professionally } \\
\text { grade; no significant effects } \\
\text { on price }\end{array}$ \\
\hline
\end{tabular}




\begin{tabular}{|c|c|c|c|c|c|c|}
\hline $\begin{array}{l}\text { (Kalyanam and } \\
\text { McIntyre, 2001) }\end{array}$ & Palm Pilot PDAs & $\$ 238$ & hedonic regression & $\begin{array}{l}\text { product type; picture? } \\
\text { number of bids }\end{array}$ & $\begin{array}{l}\text { OLS for sold items only; } \\
\text { price against positives, } \\
\text { negatives, interaction } \\
\text { terms }\end{array}$ & $\begin{array}{l}\text { Seller with } 3000 \text { total } \\
\text { feedback and } 0 \text { negatives gets } \\
12 \% \text { higher price than a seller } \\
\text { with } 10 \text { total feedback and } 4 \\
\text { negatives }\end{array}$ \\
\hline $\begin{array}{l}\text { (Livingston, } \\
\text { 2002) }\end{array}$ & golf clubs & $\$ 409$ & hedonic regression & \begin{tabular}{|l|} 
product type; minimum \\
bid; book value; secret \\
reserve?; credit card?; day \\
and time of auction close; \\
length; inexperienced \\
bidder?
\end{tabular} & $\begin{array}{l}\text { probit predicts probability } \\
\text { of sale; simultaneous ML } \\
\text { estimation of price if } \\
\text { observed, probability of } \\
\text { sale; reputation specifed by } \\
\text { dummies for quartiles of } \\
\text { positive feedback, fraction } \\
\text { of negative }\end{array}$ & $\begin{array}{l}\text { Sellers with } 1 \text { to } 25 \text { positive } \\
\text { comments receive } \$ 21 \text { more } \\
\text { than sellers with no reports. } \\
\text { Sellers with more than } 675 \\
\text { positive comments receives } \\
\$ 46 \text { more. The first } 11 \text { good } \\
\text { reports increase probability of } \\
\text { receiving a bid } 4 \% \text {, } \\
\text { subsequent reports do not } \\
\text { appear to have a statistically } \\
\text { significant effect on sale } \\
\text { probability. }\end{array}$ \\
\hline $\begin{array}{l}\text { (Lucking-Reiley } \\
\text { et al, 2000) }\end{array}$ & Coins & $\$ 173$ & hedonic regression & $\begin{array}{l}\ln (\text { book val); } \ln (\text { minbid); } \\
\text { auction length; end on } \\
\text { weekend?; Hidden } \\
\text { reserve? }\end{array}$ & $\begin{array}{l}\text { reduced form, censored } \\
\text { normal regression; } \ln (\text { high- } \\
\text { bid) vs. } \ln (\text { pos }), \ln (\text { neg) }\end{array}$ & $\begin{array}{l}\text { No statistically significant } \\
\text { effect from positive feedback; } \\
1 \% \text { increase in negative } \\
\text { feedback reduces price by } \\
0.11 \% \text {. }\end{array}$ \\
\hline $\begin{array}{l}\text { (McDonald and } \\
\text { Slawson, 2000) }\end{array}$ & $\begin{array}{l}\text { Collectible Dolls; } \\
\text { new }\end{array}$ & $\$ 208$ & hedonic regression & month & $\begin{array}{l}\text { Simultaneous regression } \\
\text { for sold items only: price } \\
\text { against bids, reputation; } \\
\text { bids against minimum bid, } \\
\text { secret reserve, reputation. } \\
\text { Various specifications of } \\
\text { reputation }\end{array}$ & $\begin{array}{l}\text { High reputation seller (90th } \\
\text { percentile of eBay rating) gets } \\
5 \% \text { higher price than low } \\
\text { reputation (10th percentile) } \\
\text { and gets more bids }\end{array}$ \\
\hline $\begin{array}{l}\text { (Melnik and Alm, } \\
\text { 2002) }\end{array}$ & $\begin{array}{l}\text { Gold coins in mint } \\
\text { condition }\end{array}$ & $\$ 33$ & hedonic regression & $\begin{array}{l}\text { gold price; closing time } \\
\text { and day; auction length; } \\
\text { credit card acceptance; } \\
\text { images; shipping charges }\end{array}$ & $\begin{array}{l}\text { reduced form, censored } \\
\text { normal regression; } \ln \text { (high- } \\
\text { bid) vs. } \ln (\text { pos }), \ln (\text { neg), } \\
\ln \text { (neutral) }\end{array}$ & $\begin{array}{l}\text { Decline of positive ratings } \\
\text { from } 452 \text { to } 1 \text { decreases price } \\
\text { by } \$ 1.59 \text { for } \$ 32 \text { items; } \\
\text { halving negative feedback } \\
\text { from } 0.96 \text { comments to } 0.48 \\
\text { comments increases price by } \\
28 \text { cents. }\end{array}$ \\
\hline
\end{tabular}




\begin{tabular}{|c|c|c|c|c|c|c|}
\hline $\begin{array}{l}\text { (Cabral and } \\
\text { Hortacsu, 2003) }\end{array}$ & $\begin{array}{l}\text { IBM Thinkpad } \\
\text { notebooks, gold } \\
\text { coins, mint coin sets, } \\
\text { Beanie Babies }\end{array}$ & $\$ 15-\$ 900$ & hedonic regression & $\begin{array}{l}\text { dummy variable for eBay } \\
\text { format change } \\
\text { date;closing time and day; } \\
\text { auction length; credit card } \\
\text { acceptance; PayPal; } \\
\text { images; whether item is } \\
\text { refurbished }\end{array}$ & $\begin{array}{l}\text { OLS; ln(highbid) vs. \% of } \\
\text { negatives, total number of } \\
\text { feedbacks, age of seller in } \\
\text { days }\end{array}$ & $\begin{array}{l}\text { Effect of \% negatives } \\
\text { increases after eBay begins to } \\
\text { report percentages in March } \\
2003 \text { (8\% price premium if \% } \\
\text { negatives declines 1 point). } \\
\text { Effect of total no. of } \\
\text { feedbacks and age of seller } \\
\text { declines after format change. } \\
\text { Effect most visible for } \\
\text { Thinkpads. }\end{array}$ \\
\hline $\begin{array}{l}\text { (Ba and Pavlou, } \\
\text { 2002) }\end{array}$ & $\begin{array}{l}\text { Music CD; Modem; } \\
\text { Windows Server } \\
\text { software CD; digital } \\
\text { camcorder }\end{array}$ & $\$ 15-\$ 1200$ & $\begin{array}{l}\text { lab experiment in the } \\
\text { field: subjects } \\
\text { responded with trust } \\
\text { level and willingness to } \\
\text { pay for auction listings } \\
\text { with different feedback } \\
\text { profiles spliced in. }\end{array}$ & $\begin{array}{l}\text { showed identical listings } \\
\text { with different feedback } \\
\text { profiles }\end{array}$ & $\begin{array}{l}\text { OLS, ANOVA of trust, } \\
\text { price premium, against } \\
\ln (\text { positive), } \ln (\text { negative) }\end{array}$ & $\begin{array}{l}\text { Buyers willing to pay } 0.36 \% \\
\text { more if feedback profile has } \\
1 \% \text { more positives, }-0.63 \% \\
\text { less with } 1 \% \text { more negatives } \\
\text { (Table } 8 \text { ). Effect is larger for } \\
\text { higher priced items. }\end{array}$ \\
\hline $\begin{array}{l}\text { (Resnick et al, } \\
2003)\end{array}$ & Vintage postcards & $\$ 13$ & field experiment & $\begin{array}{l}\text { showed matched } \\
\text { information for matched } \\
\text { items, in different display } \\
\text { format }\end{array}$ & $\begin{array}{l}\text { censored normal: } \ln (\text { ratio } \\
\text { of prices) dep variable } \\
\text { with no independent } \\
\text { variables }\end{array}$ & $\begin{array}{l}\text { Seller with } 2000 \text { positive } \\
\text { comments and } 1 \text { negative } \\
\text { fetched } 8 \% \text { higher prices for } \\
\text { matched items sold by newly } \\
\text { created seller identities with } \\
10 \text { positives on average. Sale } \\
\text { probability of large seller } 7 \% \\
\text { higher than new sellers. One } \\
\text { or two negatives for a relative } \\
\text { newcomer had no statistically } \\
\text { detectable effect over other } \\
\text { newcomers. }\end{array}$ \\
\hline \begin{tabular}{|l|} 
\{Cabral and \\
Hortacsu, 2003)
\end{tabular} & \begin{tabular}{|l} 
IBM Thinkpad \\
notebooks, gold \\
coins, mint coin sets, \\
Beanie Babies
\end{tabular} & $\$ 15-\$ 900$ & $\begin{array}{l}\text { panel regression using } \\
\text { backward-looking } \\
\text { feedback profiles of a } \\
\text { cross-section of seller }\end{array}$ & $\begin{array}{l}\text { control for seller fixed } \\
\text { effects, age in days, } \\
\text { reviewer profile }\end{array}$ & $\begin{array}{l}\text { look at the impact of first } \\
\text { vs. subsequent negatives } \\
\text { on sales growth, where } \\
\text { sales levels are proxied by } \\
\text { the number of feedbacks } \\
\text { received; look at the timing } \\
\text { between negatives }\end{array}$ & $\begin{array}{l}\text { In } 4 \text { week window after first } \\
\text { negative, sales growth rate is } \\
30 \% \text { less than in } 4 \text { week } \\
\text { window before negative; } \\
\text { second negatives arrive faster } \\
\text { than first negatives (takes } 150 \\
\text { fewer days } 202 \text { fewer } \\
\text { transactions for } 2 \text { nd negative } \\
\text { to arrive on average) }\end{array}$ \\
\hline
\end{tabular}




\section{Figure 1: Sample eBay Listing}

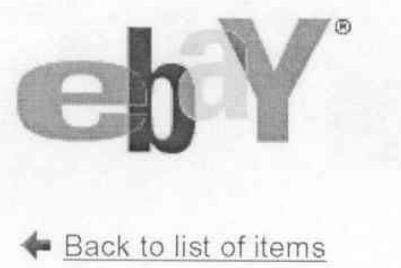

home | register | sign in | services | site map | help (?)

\begin{tabular}{|c|c|c|c|c|c|}
\hline Browse & Search & Sell & My eBay & Community & Powered By \\
\hline
\end{tabular}

Listed in category: Collectibles $>$ Autographs $>$ Historical

Lot of Nobel Prize signatures ECONOMICS

You are signed in
Item number: 2191849949

Watch this item (track it in My eBay)

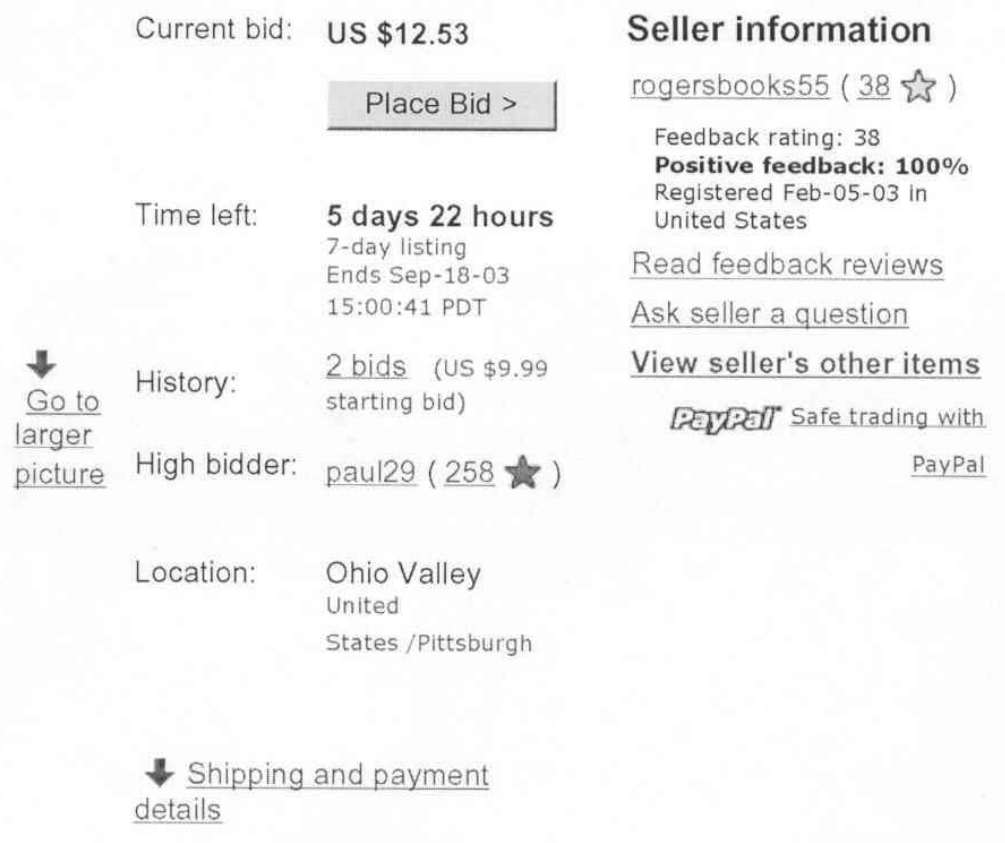

\section{Description}

This is a lot of First Day Covers and cards authentically autographed (not a pre-print or autopen) by Nobel Prize laureates in Economics (14 in all) as follows: (signed blank index cards) Paul Samuelson, Jan Tinbergen, Wassily Leontief, (FDC's) Lawrence Klein, Milton Friedman, James Meade, HARRY M. MARKOWITZ, Robert Solow, Gary Becker, Douglass North, Alan Greenspan, John Kenneth Galbraith and Alan Dershowitz and a handwritten note from James Tobin. A Certificate of Authenticity by Rogersbooks will be provided if asked for when sending payment. Domestic Priority S \& H with comfirmation is \$7.00. SEE SELLER'S OTHER AUCTIONS FOR MORE UNIQUE AUTOGRAPHS

\section{Payment}

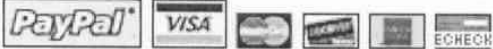

I accept the following forms of payment: 
Figure 2: Bidder Uncertainty and Winning Bids.

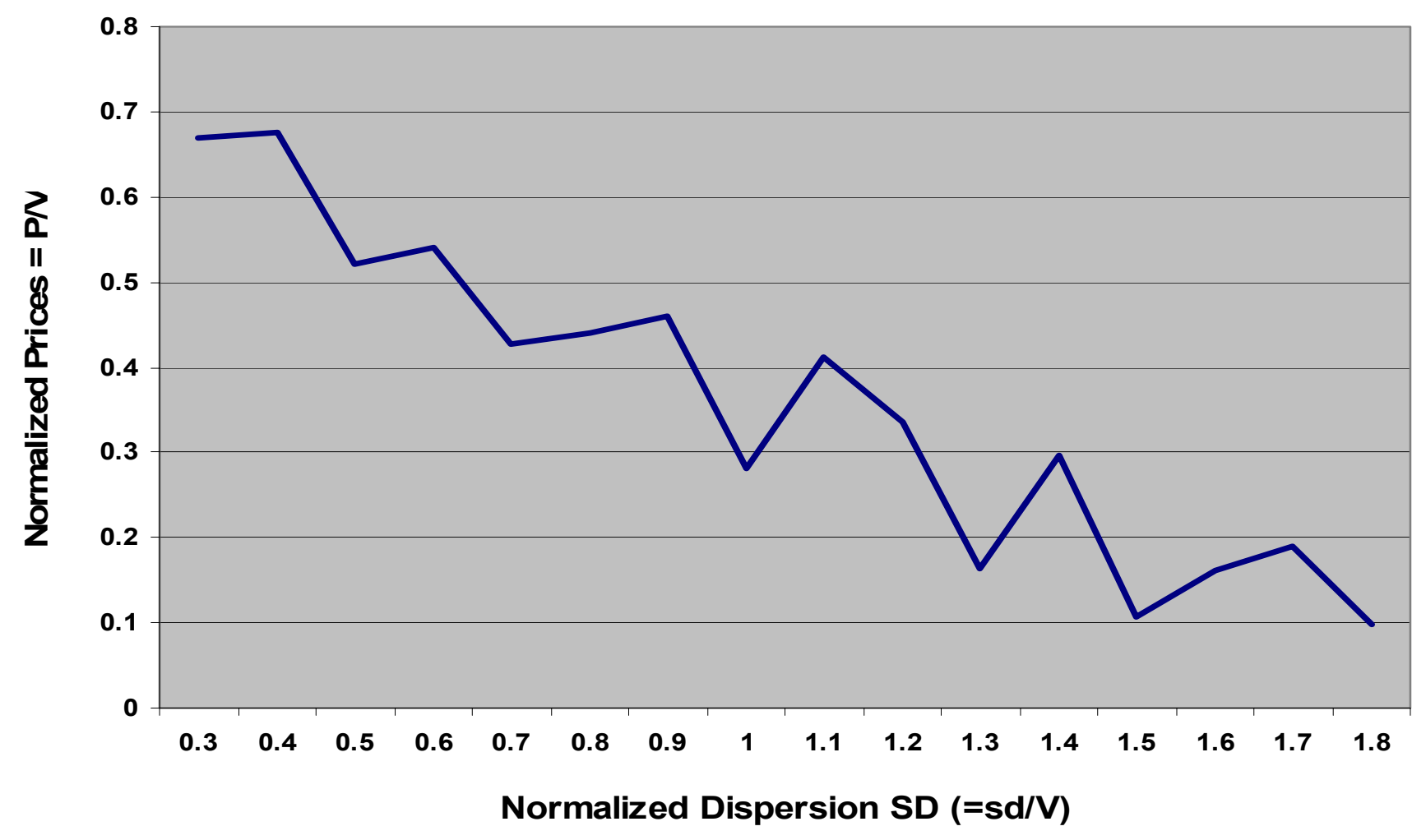

